\title{
Membangun E-Commerce Desain Baju Pada Gynied
}

\author{
Andreas Korsini Blasing ${ }^{1)}$ Muhammad Rusli' ${ }^{2)}$ \\ Sistem Informasi, Institut Teknologi dan Bisnis Kalbis \\ Jalan Pulomas Selatan Kav. 22, Jakarta 13210 \\ ${ }^{1)}$ Email: blasing.andreas909@gmail.com \\ ${ }^{2)}$ Email: muhammad.rusli@kalbis.ac.id
}

\begin{abstract}
Home Industry gynied is a business which is engaged in the design of clothes in the Bekasi area. Home Industry gynied is a clothing design fabric, where the buying and selling process is only done manually. In this ongoing system, Home Industry gynied experiencing difficulties such as lack of promoting Home Industry gynied products, therefore customers must come to the store to make purchases and payers manually. When conducting research, researchers use the waterfall method and the type of research used is qualitative. This method is used by researchers to develop sequential software systems which start from analysis, design, coding, and testing and implementation. In designing the system, the researcher uses UML modeling and in implementing the system, the researcher uses PHP and MYSQL and for his testing the researcher uses black box testing. The end result of this research is the integration of e-commerce in the sales system by the Home Industry gynied and can expand sales with a website that has been created.
\end{abstract}

Keywords: e-commerce, PHP, MYSQL, UML, Website

Abstrak: Home Industry gynied merupakan sebuah usaha yang dimana bergerak pada bidang desain baju di daerah Bekasi. Home Industry gynied merupakan clothingan desain baju, yang dimana proses jual belinya hanya dilakukan secara manual. Pada sistem yang sedang berjalan ini, Home Industry gynied mengalami kesulitan seperti kekurangan mempromosikan produk-produk Home Industry gynied oleh karena itu customer harus datang ke toko untuk melakukan pembelian dan pembayar secara manual. Pada saat melakukan penelitian, peneliti menggunakan metode waterfall dan jenis penelitian yang digunakan ialah kualitatif. Metode ini digunakan peneliti untuk mengembangkan sistem-sistem perangkat lunak secara berurut yang dimana dimulai dari analisa, desain, codingan, dan pengujian serta implementasi. Dalam perancangan sistem, peneliti menggunakan pemodelan UML dan dalam pengimplementasin sistem, peneliti menggunakan PHP dan MYSQL dan untuk pengujiannya peneliti menggunakan black box testing. Hasil akhir penelian ini adalah tercipatnya e-commerce pada sistem penjualan yang dilakukan Home Industry gynied dan dapat memperluas penjualan dengan website yang dibuat oleh peneliti.

Kata kunci: e-commerce, PHP, MYSQL, UML, Website

\section{PENDAHULUAN}

Berkembangnya ilmu pengetahuan diiringi dengan teknologi yang semakin meningkat untuk melakukan riset-riset penelitian maupun digunakan oleh perusahaan untuk memenangi atau bertahan dalam persaingan. Teknologi yang berkembang tidak hanya menggerakkan dan menolong bidang pengolahan data, tetapi juga menggerakkan bisnis dalam menjalankan usahanya. Pengarsipan data, penjualan, produktivitas dan pemasaran menjadi bagian besar dalam teknologi saat ini. Tetapi tidak hanaya itu saja, butuh sistem pendukung yang dapat berguna untuk membantu dalam suatu organisasi atau perusahaan yang dapat menjaga stabilitas eksistensinya. Sistem yang telah dikembangkan dan dikombinasikan dengan berbagai aspek untuk membantu manusia menyelesaikan sebuah pekerjaan, contohnya adalah sistem informasi. Sistem informasi adalah gabungan dari teknologi dan sumber daya dari sebuah organisasi yang terkordirnasi untuk mengolah data menjadi informasi sehingga mencapai sebuah tujuan tertentu.

Dalam kasus ini, gynied merupakan sebuah Home Industry yang bergerak dibidang desain baju. Berdasarkan hasil observasi dalam bentuk wawancara dan dokumentasi yang telah dilakukan oleh peneliti, ditemukan bahwa Home Industry gynied dalam melaksanakan transaksi penjualan dan pengelolaan data masih mengalami permasalahan karena masih menggunakan sistem yang bersifat konvensional. Oleh sebab itu Home Industry gynied, sering mengalami permasalahan pada saat pengumpulan data customer serta transaksi penjualan, yang dimana ketika melakukan pencarian data untuk pengiriman 
barang sering terjadi kesulitan karena data yang diperlukan membutuhkan waktu lama dalam proses pencarian data. Kegiatan dalam pengumpulan data dan pembuatan data laporan penjualan, Home Industry gynied membutuhkan waktu yang cukup lama. Banyaknya data transaksi penjualan yang masih dicatat secara manual menyebabkan data penjualan terjadi kekeliruan dan pencarian data-data barang keluar serta barang masuk menyebabkan terjadinya kesulitan sehingga memberikan dampak yang cukup besar dalam kegiatan dalam pembuatan laporan penjualan pada Home Industry gynied. Dengan adanya kendala yang dihadapi oleh Home Industry gynied, maka informasi yang dihasilkan menjadi kurang akurat. Home Industry gynied pun kekurangan media pemasaran dalam mengimplemtasikan produknya. Hal ini menyebabkan Home Industry gynied mengalami kekurangan pemasukan pada penjualan produk. Oleh sebab itu Home Industry gynied membutuhkan media pendukung, untuk melakukan pemasaran produk yang dibuatnya.

Dengan adanya kemunculuan website, rupanya lebih berkembang pesat dibanding dengan pemasaran melalui Koran dan pamphlet/brosur. Kehadiran dari website hampirmengubah segala fungsi bisnis, dimulai dari pemasaran sampai transaksi jual beli, tanpa harus datang ke toko tersebut. Setiap Home Industry baik itu Home Industry kecil, menengah maupun Home Industry bersekala besar yang dimana membutuhkan pengolahan data yang khusus untuk mengelola suatu data dengan cepat dan tepat, sehingga tidak terjadi banyak penumpukan tugas yang menyita waktu dan tenaga dalam menyelesaikan suatu pekerjaan. Oleh sebab itu teknologi komputer sangat membantu dalam pemasaran suatu produk yang akan di pasarkan. Internet adalah sebuah teknologi komputer yang menghubungkan satu pengguna dengan pengguna lainnya diseluruh dunia. Internet dapat memberikan akses untuk masuk ke dalam sebuah website. Maka peneliti berupaya membuat rancangan sistem berbasis website dengan mengoptimalkan teknologi komputer yang sudah tersedia.

Dengan masalah yang dihadapi oleh gynied ini, maka dibutuhkan solusi untuk mempermudah melakukan penjualan Desaign baju serta pembuatan laporan penjualan dan stok barang dengan menggunakan website. Dengan adanya website ini dapat mempermudah bagi customer untuk dapat membeli desaign baju, serta customer dapat mendesain sendiri sesuai dengan kamuannya yang diinginkan dan juga dapat mendapatkan informasi produk yang terkait.

\section{METODE PENELITIAN}

Pada penelitian ini, peneliti menggunakan jenis penelitian kualitatif yang dimana menggunakan metode waterfall. Penelitian kualitatif, ialah merupakan penelitian tentang riset yang bersifat deskriptif, cenderung menggunakan analisis dan lebih menamakan proses maknanya. Pada proses dan makna lebih ditonjolkan dalam penelitan kualitatif. Landasan teori pun dimanfaatkan sebagai pemandu agar penelitian fokus dengan fakta yang ada di lapangan. Selain itu pula, landasan teori ini juga bermanfaat untuk memberikan gambaran tentang latar penelitan serta sebagai bahan pembahasan hasil penelitan, yang dimana menggunakan teori-teori yang sudah ada. Penelitian kualitatif bersifat umum, fleksibel, dan dinamis.

Teknik wawancara merupakan teknik pengumpulan data yang dilakukan peneliti melaluli tahap tatap muka dan tanya jawab dengan pemilik Home Industry gynied. Pada teknik ini, peneliti bertujuam agar memahami permasalahan yang dihadapi Home Industry gynied. Peneliti tidak hanya mewawancari pemilik Home Industry gynied, melainkan peneliti mewawancarai customer, untuk memperoleh data serta permasalahan yang terjadi pada Home Idustry gynied. Dengan demikian, peneliti dapat memastikan bahwa sistem yang akan dibuat akan memenuhi kebutuhan Home Indsutry gynied.

Pada tahap observasi, peneliti memperhatikan secara langsung sistem penjualan pada Home Industry gynied. Dengan tahap observasi ini, peneliti dapat mengetahui kesalahan pada sistem yang sedang berjalan pada Home Industry gynied. Setelah melakukan tahap wawancara dan observasi, peneliti menggunakan metode waterfall untuk membuat sistem. Adapun tahapan-tahapan waterfall adalah sebagai berikut, yang ada pada Gambar 1 .

Dalam melakukan penelitian ini, peneliti menggunakan metode pengujain black box testing untuk Home Industry gynied yang berbasis website. Pengujian black box menekankan pengujian pada fungsionalitas terhadap sistem dari setiap halaman menu yang ada pada aplikasi E-commerce Home Industry gynied.

\section{HASIL DAN PEMBAHASAN}

\section{A. Sistem Informasi}

Sebuah sistem yang dirancang untuk mengelola data dan mengintegrasikan seperangkat elemen atau komponen yang saling terkait untuk mencapai 


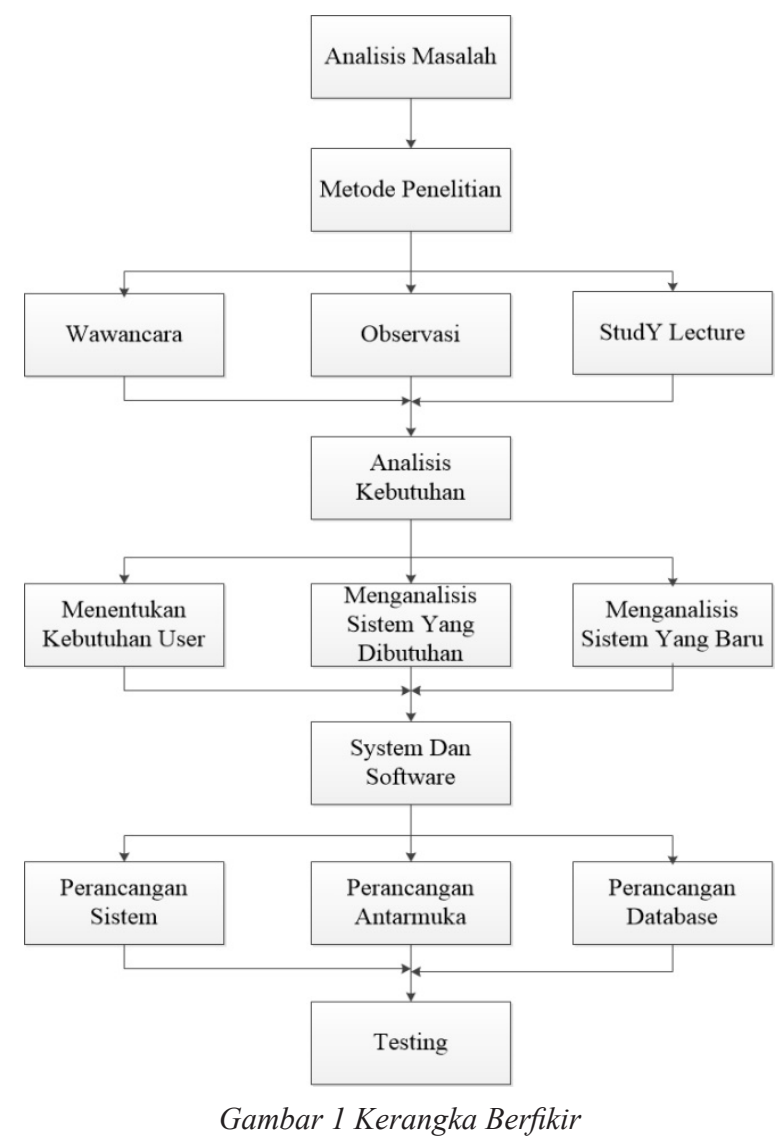

sebuah tujuan tertentu. Informasi yang dihasilkan dapat menjadi alat bantu pengambilan keputusan perusahaan atau manajer strategy dalam suatu perusahaan. Dengan demikian perusahaan dapat tetap mempertahankan bahkan meningkatkan kualitasnya dalam persaingan bisnis. Dari konsep sistem informasi diatas, sistem didefinisikan sebagai sekumpulan prosedur yang saling berkaitan satu sama lain dan saling terhubung untuk melakukan suatu tugas secara bersama-sama dan saling mendukung. Secara garis besar, sebuah sistem terdiri atas tiga komponen utama. Ketiga komponen tersebut mencakup software, hardware, dan brainware. Ketiga komponen ini saling berkaitan satu sama lain [1]].

Informasi, ialah merupakan hasil pengelolaan data dari satu atau berbagai sumber, yang kemudian diolah, sehingga memberikan nilai, arti, dan manfaat. Dalam proses ini memerlukan teknologi dalam mengolah data menjadi sebuah informasi. Informasi dapat diperoleh dari media cetak (koran, majalah, buku) maupun media elektronik seperti radio, televisi dan internet [2].

Sistem informasi adalah suatu sistem didalam suatu organisasi yang mempertemukan kebutuhan pengelolaan transaksi harian, mendukung operasi, bersifat manajerial, dan kegiatan strategi dari suatu organisasi dan dapat menyediakan pihak luar tertentu dengan laporan-laporan yang dibutuhkan []] .

\section{B. Sitem Informasi Penjualan.}

Sistem infomasi penjualan adalah suatu sistem informasi yang mengorganisasikan serangkaian prosedur dan metode yang dirancang untuk menghasilkan, menganalisa, menyebarkan dan memperolehinformasiguna mendukung pengambilan keputusan mengenai penjualan, dan menghasilkan informasi yang terkait dengan penjualan, cara mengumpulkan data-data seperti faktur penjualan itu salah satu cara untuk menghasilkan informasi yang di perlukan. Seperti informasi berupa laporan penjualan setiap jenis barang berguna bagi manajemen untuk mengevaluasi barang yang tidak laku dijual [4].

\section{E-commerce}

Perdagangan elektronik atau e-dagang (bahasa Inggris: electronic commerce atau e-commerce) adalah penyebaran, pembelian, penjualan, pemasaran barang dan jasa melalui sistem elektronik seperti internet atau televisi, www, atau jaringan komputer lainnya. e-commerce dapat melibatkan transfer dan elektronik, pertukaran data elektronik, sistem manajemen inventori otomatis, dan sistem pengumpulan data otomatis.

Industri teknologi informasi melihat kegiatan e-commerce ini sebagai aplikasi dan penerapan dari e-Business yang berkaitan dengan transaksi komersial, seperti: transfer dan secara elektronik, SCM (supply chain management), e-Marketing atau pemasaran online, pemrosesan transaksi online (online transacfion processing), pertukaran data elektronik (Electronic data interchange/EDI), dan lain-lain []ㅡ.

Menurut Jony Wong (2010), pengertian dari e-commerce adalah pembelian, penjualan, dan pemasaran barang serta jasa sistem elektronik. Seperti televisi, radio, dan jaringan komputer atau internet. E-commerce meliputi transfer dana secara elektronik, pertukaran dan pengumpulan data. Semua diatur dalam sistem manajemen inventori otomatis [ 6$]$.

Sedangkan menurut Mahir Pradana (2015), e-commerce itu adalah proses bisnis pembelian, penjualan, mentransfer atau bertukar produk/ jasa atau informasi yang melalui jaringan internet. Dengan mengambil bentuk-bentuk trandisioal dari proses bisnis dan memanfaatkan jaringan social melalui internet, strategi bisnis dapat berhasil jika dilakukan dengan benar, yang akhirnya meningkatkan pelanggan serta proses jual beli antar konsumen dan penjual produk. Keputusan pembelian pembelian pelanggan di pengaruhi persepsi, motivasi, 
pembelajaran, sikap dan keyakinan. Persepsi dipantulkan ke pada pelanggan bagaimana mengatur, memilih, dan menginterpretasikan informasi untuk membentuk pengetahuan. Motivasi tercermin keinginan pelanggan untuk memenuhi kebutuhan mereka sendiri []].

\section{PHP}

Hypertext Preprocesor (PHP) adalah suatu bahasa pemrograman yang digunakan untuk menerjemahkan baris kode program menjadi kode mesi yang dapat di mengerti oleh komputer yang bersifat sever-side yang dapat ditambahkan ke dalam HTML [ㅁ] . Fungsi PHP adalah membuat atau mengembangkan situs web statis atau situs web dinamis atau aplikasi Web. Walaupun sebenarnya bukan hanya PHP bahasa pemrograman yang bisa digunakan untuk memuat website.

\section{E. HTML}

Hyper Text Markup Language (HTML). Adalah sekumpulan simbol-simbol atau tag-tag yang dituliskan dalam sebuah file yang digunakan untuk menampilkan halaman pada web browser. Tagtag HTML selalu diawali dengan $<\mathrm{x}>$ dan diakhiri dengan $</ x>$ dimana $x$ tag HTML itu seperti $b, i$, $u$, dan sebagainya [9].

Secara umum, fungsi HTML adalah untuk mengelola serangkaian data dan informasi sehingga suatu dokumen dapat diakses dan ditampilkan di Internet melalui layanan web. Lalu, adapun 3 fungsi HTML yang lebih spesifik yaitu: Membuat halaman web; dan Menampilkan berbagai informasi di dalam sebuah browser Internet. Membuat link menuju halaman web lain dengan kode tertentu (hypertext).

\section{F. Entity Relationship Diagram (ERD)}

Entity Relationship Diagram (ERD) adalah gambar atau diagram yang menunjukkan informasi dibuat, disimpan, dan digunakan dalam sistem bisnis. Entitas biasanya menggambarkan jenis informasi yang sama. Dalam entitas digunakan untuk menghubungkan antar entitas sekaligus menunjukkan hubungan antar data. Entity Relationship Diagram (ERD) bisa juga digunakan untuk menunjukkan aturan-aturan bisnis yang ada pada sistem informasi yang akan dibangun [10].

\section{G. Database}

Basis Data (Database) merupakan kumpulan data yang saling berkaitan dan berhubungan satu sama lain, tersimpan di perangkat keras komputer dan menggunakan perangkat lunak untuk memanipulasinya. Data perlu disimpan dalam basis data (database) untuk keperluan penyedian informasi lebih lanjut [11]. Dengan adanya basis data (database) data yang tersimpan pada komputer, akan tersusun rapih serta data tidak akan tertutup dengan data yang lain. Serta data menghindari adanya duplikasi dari suatu data dan memudahkan dalam mengupdate dan menghapus data yang ada pada komputer karena data sudah tersusun rapih pada tempat penyimpanan.

\section{H. Website}

Website atau situs dapat diartikan sebagai kumpulan halaman-halaman yang digunakan untuk menampilkan informasi teks, gambar diam atau gerak, animasi, suara dan atau gabungan dari semuanya, baik yang bersifat statis maupun dinamis yang membentuk satu rangkaian bangunan yang saling terkait atau berhubungan, yang masing-masing dihubungkan dengan jaringan-jaringan halaman. Hubungan antara satu halaman web dengan halaman web yang lainnya disebut Hyperlink, sedangkan teks yang dapat dijadikan media penghubung disebut Hypertext.

Ada beberapa hal yang dipersiapkan untuk membangun website, maka harus tersedia unsurunsur pendukungnya sebagai berikut: Nama Domain (Domain Name/URL-Uniform Resource Locator); Rumah Web (Website Hosting); dan Content Management System (CMS) [12]. Peneliti melakukan pengembangan sistem dengan System Development Life Cycle menggunakan waterfall model. Metode ini memiliki beberapa tahapan yang harus dilakukan. Seperti pada Gambar 2.

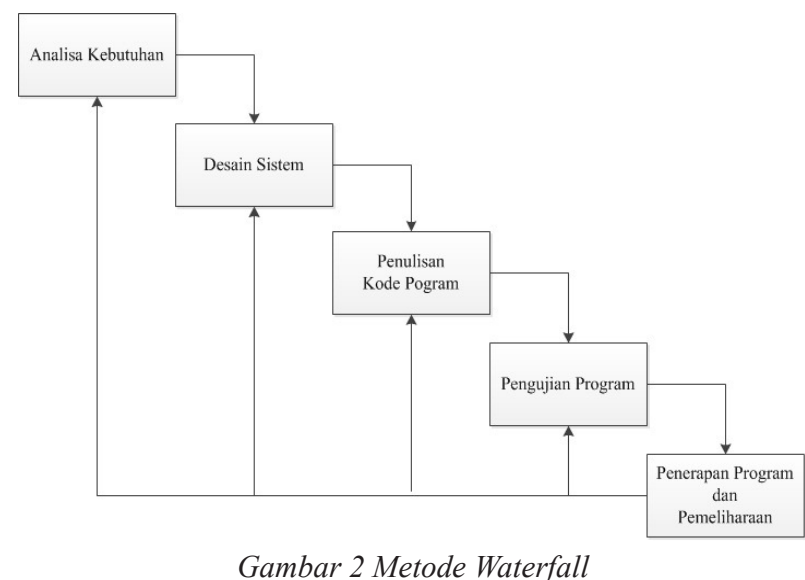

Berikut ini tahapan-tahapan pengembangan waterfall yang dilakukan peneliti: Analisis Kebutuhan, pada tahap ini spesifikasi kebutuhan perangkat lunak/ software perluuntuk didokumentasikan sertakegunaan perangkat lunak/software yang diharapkan pengguna/ user; Desain Sistem, pada tahap desain sistem ini, 
di lakukan sebelum melakukan pengcodingan. Di tahap ini, desain sistem bertujuan untuk memberikan gambaran antarmuka yang dimana seharusnya di kerjakan; Penulisan Kode Program, tahapan dimana semua desain diubah menjadi kode-kode program dan kode program yang dihasilkan berupa modulmodul yang akan diintergrasikan menjadi sistem yang lengkap; Pengujian Program, pada tahap pengujian program ini dilakukan penggabungan antara modulmodul yang sudah dibuat dan meminimalisirkan kesalahan pada software yang telah dibuat dengan melakukan pengujian/testing; Pendukung dan Pemeliharaan, ini merupakan tahap terakhir dari model waterfall. Perangkat lunak yang sudah jadi, dilakukan pemeliharaan serta termasuk dalam memperbaiki kesalahan yang tidak ditemukan pada langkah sebelumnya.

Berdasarkan sistem yang berjalan maka peneliti mengusulkan sistem yang baru. Desain usecase sistem yang diusulkan dipaparkan dalam Gambar 3:

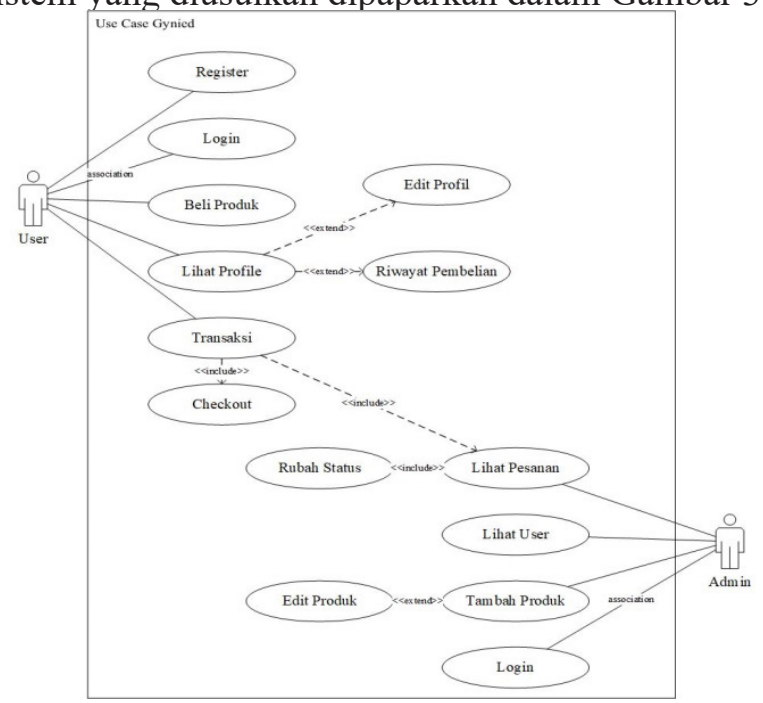

Gambar 3. Usecase Diagram

Dengan adanya sistem baru yang diusulkan oleh peneliti untuk Home Industry gynied, diharapkan proses penjualan dan pembelian berjalan dengan baik dan lancer.

Implementasi merupakan tahapan peletakan sistem yang sudah dibuat berbdasarkan analisis, perancangan serta codingan ke dalam bahasa

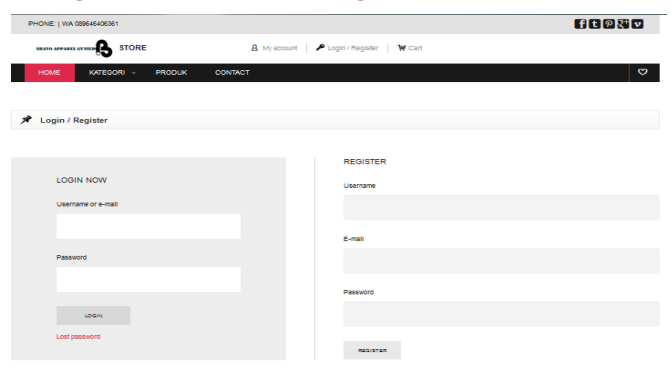

Gambar 4 Antarmuka Website Register pemrograman, merupakan beberapa hasil implementasi sistem di Home Industry gynied.

Berdasarkan tahap-tahapan yang sudah dijabarkan sebelumnya, implementasi sistem yang sudah dirancang dijabarkan dalam Gambar 4 sampai dengan Gambar 12, sebagai berikut:

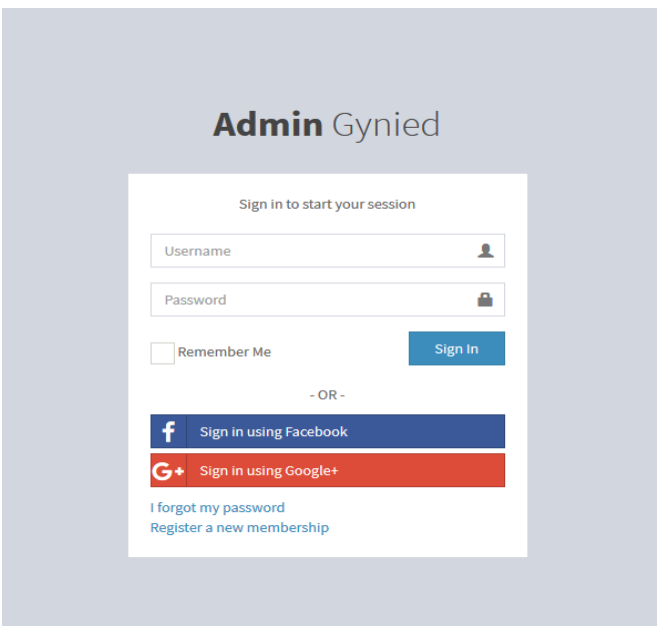

Gambar 5 Antarmuka Login Admin

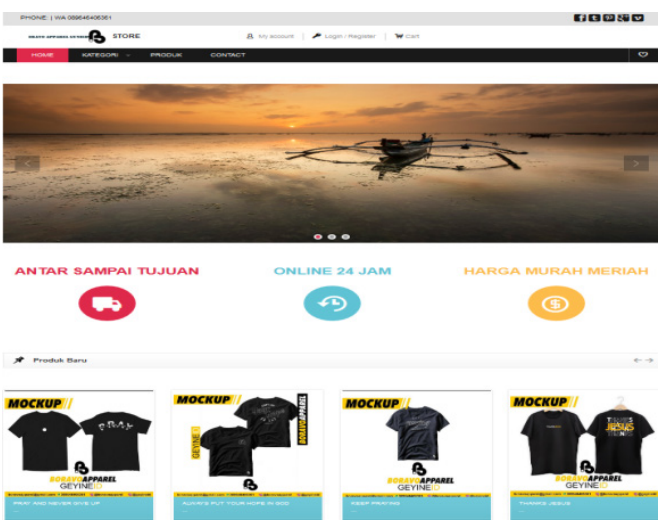

Gambar 6 Antarmuka Home
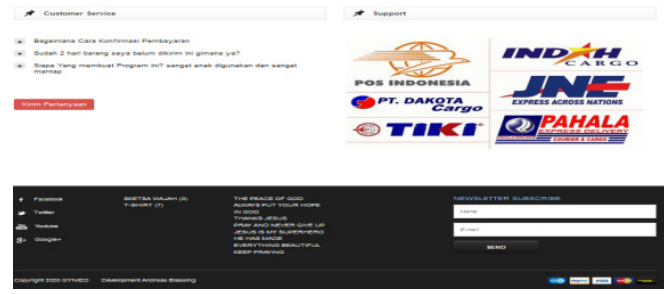

Gambar 7 Antarmuka Pelanggan

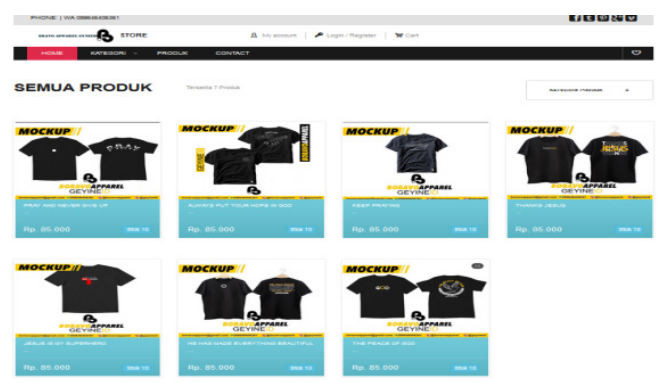

Gambar 8 Antarmuka Produk 


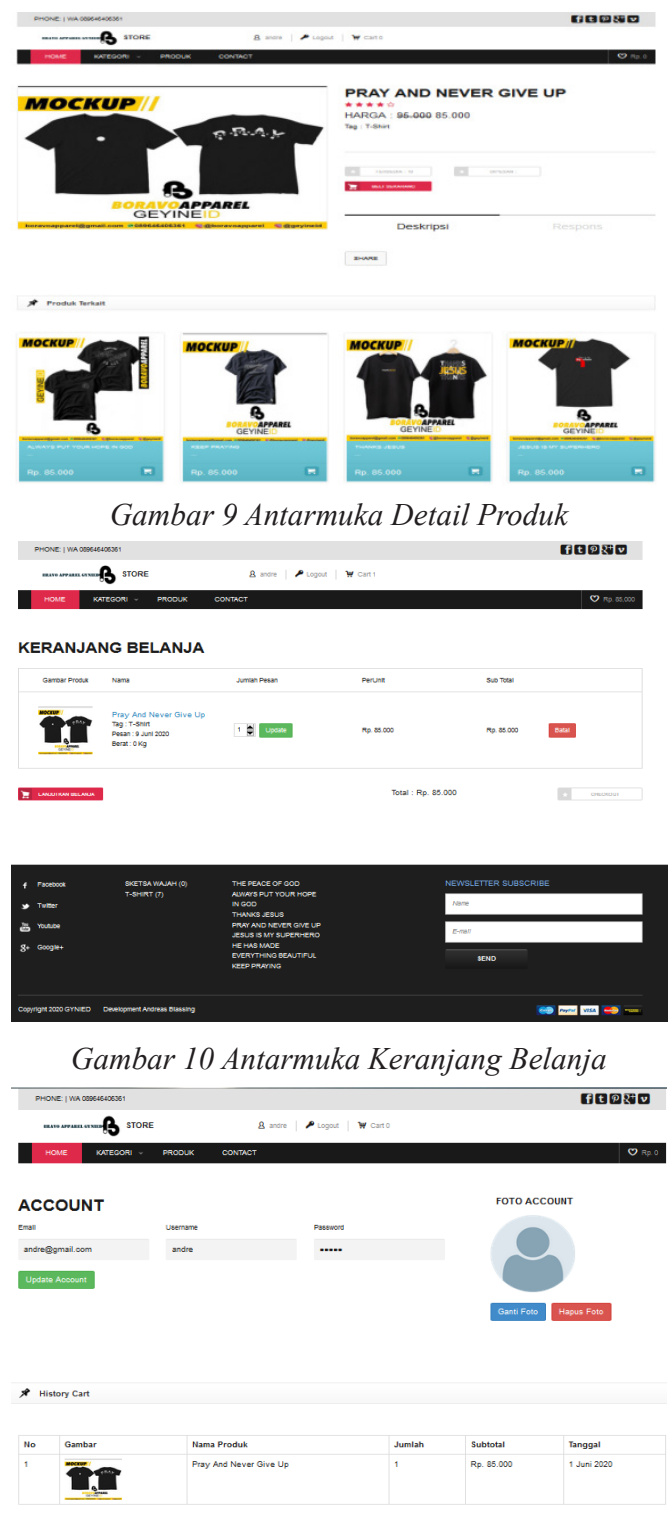

Gambar 11 Antarmuka Profil User

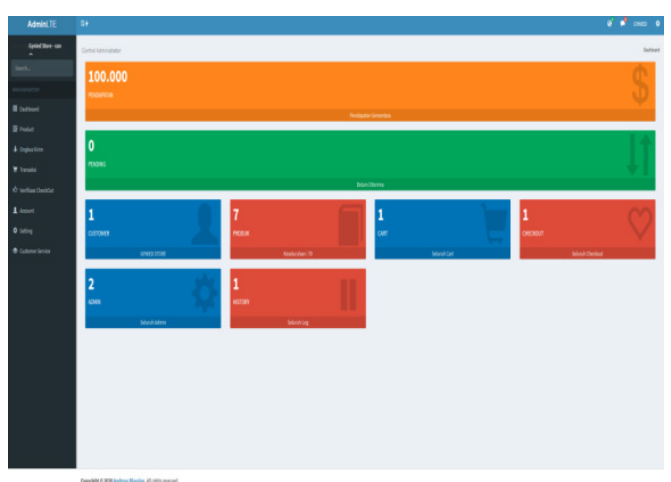

Gambar 12 Antarmuka Admin

\section{SIMPULAN}

Pada penelitian ini dihasilkan dalam Membangun e-commerce Desain Baju Pada Gynied yang dimana menggunakan website dalam mengintegrasikan penjualan desain baju dengan tanpa harus datang ke toko saat akan membeli produk. Dengan adanya website ini, dapat mempermudah konsumen dalam melakukan transaksi pembelian produk tanpa harus dating ke toko karena semua produk yang di jual oleh Home Industry gynied, sudah ada di website yang sudah dibuat. Serta dapat mempermudahnya pemilik mengelolah data input dan output pada saat pembuatan laporan dan dalam pembuatan laporan menjadi lebih rapih dan tidak gampang hilang.

\section{DAFTAR RUJUKAN}

[1] P. A. E. Pratama, "sistem," in Sistem Informasi dan Implemetasinya. Bandung, Indonesia: DEEPUBLISH, 2015, pp. 7-8.

[2] P. A. E. Pratama, Konsep Sistem Informasi. Bandung, Indonesia: DEEPUBLISH, 2015.

[3] J. Hutahaen, "Sistem Informasi," in Konsep Sistem Informasi. Yogyakarta, Indonesia: DEEPUBLISH, 2014, p. 13.

[4] T. Sutabri, Konsep Sistem Informasi. Yogyakarta: CV. ANDI OFFSET, 2012.

[5] T. Sutabri, Konsep Sistem Informasi. Yogyakarta, Indonesia: CV. ANDI OFFSET, 2012.

[6] J. Wong, "E-commerce," in Internet Marketing for Beginners. Jakarta, Indonesia: PT. Elex Media Komputindo, 2010, p. 33.

[7] M. Pradana, "KLASIFIKASI BISNIS E-COMMERCE DI INDONESIA," MODUS, vol. Vol 27, no. ISSN 0852-1875, p. 15, 2015.

[8] S. V. Putratama, Pemrograman Web dengan Menggunakan PHP dan Framework Codeigner. Yogyakarta: DEEPUBLISH, 2016.

[9] Anhar. "html," in Paduan menguasai PHP \& MySQL secara otodidak, Sudarma, Ed. Jakarta Selatan, Indonesia: mediakita, 2010, p. 40.

[10] H. A. Fatta, Analisis Dan Perancangan Sistem Informasi Untuk Keunggulan Bersaing Perusahaan Dan Organisasi Modern. Yogyakarta: CV. ANDI OFFSET, 2007.

[11] T. Sutabri, Konsep Sisem Informasi. Yogyakarta: CV. ANDI OFFSET, 2012.

[12] R. Hidayat, Cara Praktis Membangun Website Gratis. jakarta, indonesia: PT Elex media Komputindo, 2010, p. 2. 